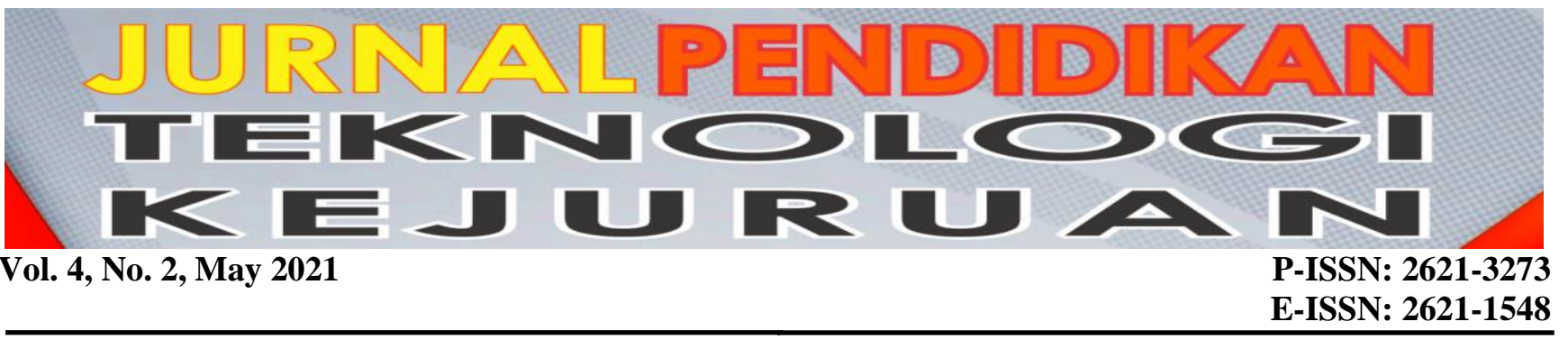

\title{
Development of Workshop Work Learning Module and Technical Drawing by Using the EPUB
}

\author{
Finico1*, Hasan Maksum² \\ ${ }^{1}$ Vocational High School 1 Sutera \\ ${ }^{2}$ Faculty of Engineering, Universitas Negeri Padang \\ *Corresponding author, e-mail: finico181080@gmail.com ${ }^{1}$, hasan@ft.unp.ac.id ${ }^{2}$
}

\begin{abstract}
This study aims to develop a learning module for Workshop Work and Technical Drawing using EPUB for class X TAV students at SMKN 1 Sutera. This research is a series of processes or activities carried out to produce Workshop Work and Engineering Drawing learning modules using EPUB based on development theory. The purpose of developing a workshop work learning module and technical drawings using the EPUB is to produce a valid and practical learning module. The learning module developed is based on the ADDIE development model, which consists of the analysis, design, and development stages. development), implementation (implementation), and evaluation (evaluation). The first stage, analysis, is to analyze before product development is carried out. The second stage, Design, the design stage begins by determining the main concepts contained in the workshop work and engineering drawing subjects. Then the third stage of Development, carrying out product development through designing the components of the learning module, in this development process carried out is conducting validation tests, and practicality regarding products by experts. Furthermore, the fourth stage is Implementation, the implementation stage can be interpreted as a realization step of the design and development stage. The last stage is the Evaluation stage, which is taking action on the treatment of the learning module with EPUB that has been tested. Based on the validation of the learning module that has been carried out on the media expert validator, the value is 0.94 with a valid interpretation. "Furthermore, for material expert validation, the value is 0.89 with a valid interpretation. So it can be concluded that the developed learning module is feasible to use to improve the learning outcomes of the Workshop Work and Technical Drawing Class X TAV Students at SMK Negeri 1 Sutera. After the learning module is declared valid, then it is followed by practicality testing of teacher respondents who obtained the value practicality of $92.49 \%$ with very practical interpretation. While the practicality value based on student respondents was 82.39 with practical interpretation. However, overall practicality is very practical.
\end{abstract}

Keyword: Learning Module Development, Using The EPUB

\section{INTRODUCTION}

West Sumatra is one of the areas which is the red zone. So that learning in West Sumatra is carried out by means of online. Online learning in West Sumatra is not only conducted in Koats, all areas affected by Covid also conduct online learning, one of which is the southern coastal district. On the south coast there are SMA and SMK and equivalent. With the outbreak of this outbreak, all schools on the south coast are also conducting online learning. Online learning is carried out by delivering material online to students. This is actually less efficient to do, especially in SMK, because SMK uses more practice to hone the abilities of students. To support efficient learning, effective teaching materials are needed.
Good teaching materials are teaching materials that contain all the material that has been stated in the curriculum in a concise, concise and clear manner. So that it is easy to use by students. This online learning indirectly asks for the skills of teachers in utilizing existing technology, due to limitations in explaining the material directly, so that teaching materials are needed that can support the delivery of material optimally.

One of the teaching materials that can be used is the learning module. Where the learning module is a learning tool or device where materials, methods, and evaluations are made systematically and structured in an effort to achieve the expected competency goals. Modules are designed specifically and clearly based on the speed at which each student understands, thus 
encouraging students to learn according to their abilities (Nasution, 2009).

Based on observations and direct observations made on SMKN 1 Sutera, several problems were found, including the learning module that teachers often use is less attractive. The module is simple, the delivery of the material contained in the mode is less coherent and systematic. So that students do not understand and lack of participation in learning. Then the learning is carried out online, providing a special challenge for the teacher to prepare suitable teaching materials for students.

Based on the results of observations, it can be denied that out of 34 students of class X TAV 1 at SMKN 1 Sutera, the average student has a score below the SKM set by the school. As for the 34 students, only $38.23 \%$ or only 13 people who achieved the SKM score and the remaining $61.77 \%$ had scores below the SKM. The next problem that was found was that part of the learning was owned by students, this could be seen from the students' responses in the courageous learning process. Then, the teacher cannot study students intensively through bold learning, so a learning module is needed that can support the learning process in a bold way that students will learn more easily and quickly, and can be learned whenever.

Departing from the problems that occur, the solution is to develop a learning module using EPUB. The development of the learning module is carried out using EPUB because the EPUB has attractive page display characteristics, the font size and paragraph settings in the EPUB file will adjust to the screen size, so that without zooming in and zooming out the letters will load by themselves. Then, you can insert sound, image or video into the EPUB file and the size is relatively small.

EPUB is an electronic book format that can be opened on electronic devices, such as computers, tablets, smartphones and even cell phones. The making of Epub format digital books (* .epub) uses HTML and xHTML languages which are open and can be used on any device (Rianto, 2012). EPUB can also be defined as a type of book with the standard file format for digital books. The epub format itself was first developed by the International Digital Publishing Forum (IDPF) (Susanto, 2011).

Based on the problems that have been stated, the researchers are interested in examining more deeply the problems encountered in a study entitled Development of Workshop Work Learning Modules and Technical Drawing Using EPUB. It is hoped that this research can provide alternative solutions in solving problems that occur at school. So that it leads to improving student learning outcomes.

Based on the problem boundaries that have been described, the formulation of the problem, namely, What is the appropriate form of learning module used in Workshop Work and Engineering Drawing subjects for class X TAV students at SMK, what is the validity and practicality of the Workshop Work learning module and Technical Drawing for class $\mathrm{X}$ TAV students at SMK. Based on the formulation of the problem, the objectives of developing the learning module are as follows, Creating a learning module that is suitable for use in Workshop Work and Engineering Drawing subjects for class $\mathrm{X}$ TAV students in SMK and knowing the validity and practicality of the Workshop Work learning modules and technical drawings for class $\mathrm{X}$ students. TAV at SMK.

\section{METHOD}

\section{A. Figure and Table}

The type of research used is research and development (Research and Development). Research and Development (R\&D), namely the stages in order to develop an existing product that can be justified (Sudjana, 2005).

R\&D research can also be defined as research and development methods, namely research methods that are used to create certain products and carry out testing the effectiveness of the products created (Sugiyono, 2012).

This research is aimed at developing the Workshop Work and Technical Drawing learning module through systematic steps to then test its feasibility. This study uses the ADDIE development model, namely Analysis, Design, Development, Implementation, and Evaluation (Branch, 2009).

This research procedure was adapted from the ADDIE development model, which is a development model composed of five steps, namely: analysis, design, development, implementation and evaluation. The ADDIE model can be used as a model when developing teaching materials or learning methods. The first step, analysis is interpreted as a process of analysis before carrying out development, including needs analysis and analyis of student characteristics. 
Furthermore, design, material preparation and learning module creation flow, display design creation, and evaluation tool planning, then development, carry out product development through the manufacture of learning module components and continue with expert validation. Then carried out the packaging. The fourth stage is implementation, which is trying out the learning modules that have been made to students and providing preliminary and final tests as well as practicality questionnaires. The fifth stage is evaluation, an evaluation of the learning module is carried out in order to obtain a post test score and obtain the expected product.

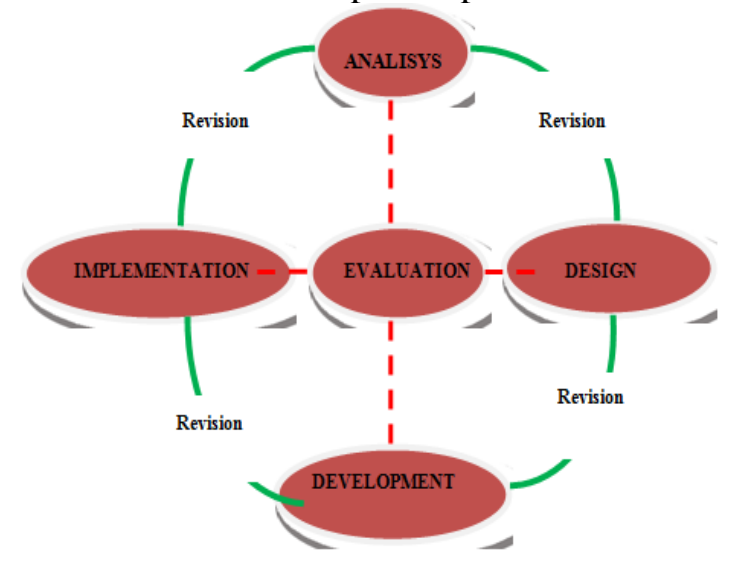

Figure 1. Model ADDIE

\section{B. References}

Learning tools or means in which there are materials, methods, and evaluations that are made systematically and structured as an effort to achieve the expected competency goals which are commonly called modules. Modules are designed specifically and clearly based on the speed of understanding of each student, so that it can encourage students to learn according to their abilities. According to (Majid, 2006) a module is a book written with the aim that students can learn independently without teacher guidance, so that the module contains at least the basic components of teaching materials that have been previously mentioned. This makes students required to study independently in order to increase learning motivation and learning outcomes.

Some situation modules, for example, are in the form of simple and attractive learning tools, contain a series of learning activities that have been systematically arranged, and contain learning objectives that have been made as well and as clearly as possible, so that students can learn individually and independently. A module can be said to be good and complete if it has the following characteristics (Azwar, 2012).

1. (Self Instructional)

2. (Self Contained)
3. (Stand Alone)

4. (Adaptive)

5. (User Friendly)

According to (Rivai, 2011) the objectives of using modules are, among others, so that educational goals can be achieved effectively and efficiently. Students can follow the learning program according to their speed and ability, learn more independently, can see their own learning outcomes.

With the existence of modules that are in accordance with student characteristics and learning objectives, the level of students' understanding of the lessons will be improved. (Nasution, 2009) states that the purpose of using modules in learning is as follows:

1. Open opportunities for students to learn at their own pace.

2. Open opportunities for students to learn in their own way, because they use different techniques to solve certain problems based on their respective backgrounds and habits..

Based on the expert's opinion, it can be concluded that the purpose of learning using modules is to make it easier for students to understand learning material that can be used individually or in groups where students can learn according to their background knowledge, speed and ability in learning..

Epub is a type of book with the standard file format for digital books. The epub format itself was first developed by the International Digital Publishing Forum (IDPF) (Asyhar, 2011). Epub is an electronic book format that can be opened on electronic devices, such as computers, tablets, smartphones and even cell phones. Creation of Epub format digital books (* .epub) using HTML and xHTML languages which are open and can be used on any device.

In fact, the epub digital book format is almost the same as the pdf, as well as a lightweight electronic book format and supports both video and audio. However, the epub and pdf formats have differences on the display side when opened via different devices. If the pdf format is opened through a different device, the display will remain the same according to the width and length of the initial creation (fix). If a pdf electronic book with A4 paper size is opened via an android smartphone device that has the size of playing paper, then to read it you must first enlarge it. Of course this really disturbs the reading process.

Among the ebook formats that are scattered on the internet, if you use the ebook as a medium for reading, then epub is the right format and suitable to choose from. Because epub has many features or features that 
are different from other electronic book formats. Among them (Asyhar, 2011):

1. Format that is open and can be obtained for free.

2. Can be opened and read through any device using the assistive application to open epub.

3. Supports video and audio in it to understand the contents in the epub e-book.

4. There is a feature to adjust the text size according to taste.

5. Support for DRM.

6. Styling css.

7. A more dynamic display, adjusting the display size according to the size of the device used

The epub function specializes in reading media via electronic devices, as an alternative to very thick and heavy box books. In addition, epub itself can be used as a complete information medium and as a learning book through electronic devices that are easy to understand, because epub also supports video and audio files in it (Asyhar, 2011).

A workshop is a place where a mechanic does his job serving repair and maintenance services. Workshop equipment is an integral part of the performance of a mechanic's work. A mechanic must be able to master and use all workshop equipment properly, without making mistakes in work. While working, a good mechanic always pays attention to work safety, both for the facilities or various things that support the implementation of work, including the safety of the mechanic's soul itself, work tools and materials in the workshop (Maran, 2007). Workshop work techniques are subjects that study the planning of practical tools and equipment management systems, the application of electronic engineering drawings based on ANSI and DI N standards, the application of workshop work based on occupational health and safety standards according to regional and international laws, and the basis for mechanical work in the field of fabrication engineering. electronic equipment. The scope of workshop work engineering materials is workshop management, tool equipment management, electronic engineering drawings, occupational health and safety, and mechanical work.

\section{RESULT}

The development of the Workshop Work and Technical Drawing learning module using EPUB for class X TAV students at SMKN 1 Sutera is a series of processes or activities carried out to produce a Workshop Work and Technical Drawing learning module using EPUB based on development theory. The purpose of developing a workshop work learning module and technical drawings using this EPUB is to produce a valid and practical learning module. The learning module developed is based on the ADDIE development model, which consists of stages (analysis), (design), (development), (implementation), and (evaluation).

The first stage, analysis, is to analyze before product development is carried out. The purpose of the analysis is to interpret coherently and systematically, at this stage the researcher analyzes matters relating to the development of the learning module, namely: needs analysis, analysis of student characteristics and analysis of learning objectives. Needs analysis was carried out through surveys and interviews with research respondents. Furthermore, the analysis of student characteristics is carried out by identifying the character of students who will use the learning module based on interviews with the teacher of the Workshop Work and Technical Drawing subject for the class, that the character of the students prefers guidance in learning, and likes the various exercises presented by the teacher. Through the analysis of student characteristics, researchers are able to determine the type of approach that is suitable in carrying out the teaching and learning process.

The second stage of design, "the design stage begins by establishing the main concepts contained in the workshop work and engineering drawings subject and then designing and compiling them into a valid and practical learning module such as arranging the material and learning module flow, designing the display design, and determining evaluation tool. then the Third Stage of Development, carrying out product development through designing the components of the learning module, in this development process carried out is conducting validation tests, and practicality

Furthermore, the fourth stage of implementation, the implementation stage can be interpreted as a step towards the realization of the design and development stages. The implementation stage means implementing things related to the development of the learning module, namely testing the learning module on the Engineering Drawing and Workshop Work learning at SMKN 1 Sutera. Implementation of the learning module is carried out after completing the validation stage.

The last stage is the Evaluation stage, which is taking action on the experimental treatment of the learning module with EPUB. Actions were taken in an effort to improve the learning module with the EPUB that was made, including making final revisions after the developed learning module was implemented in Workshop Work and Technical Drawing learning and producing a final product that was suitable for use in 
the learning process of Workshop Work and Technical Drawing.

Based on the validation of the learning module that has been carried out on the media expert validator, the value is 0.94 with a valid interpretation. Furthermore, for material expert validation the value was 0.89 with a valid interpretation. So it can be concluded that the developed learning module is feasible to be used to improve learning outcomes in Workshop Work and Technical Drawing for Class X TAV Students at SMK Negeri 1 Sutera. After the learning module is declared valid, then it is followed by practicality testing of teacher respondents who obtained a practicality value of $92.49 \%$ with a very practical interpretation. While the practicality value based on student resThe results of this study are relevant to the research by Sugeng Haryadi (2016) who has conducted research on the development of printed teaching materials for engineering drawing subjects class $\mathrm{X}$ of the audio video engineering expertise program of SMK Muhammadiyah 3 Yogyakarta. The result is that the teaching materials developed are appropriate according to experts and users (teachers and students). Furthermore, this research is also relevant to the research conducted by Anang Prasetyo (2015) who has conducted research on the development of jobsheets for electronic workshop work techniques as a practical learning medium for class X students at SMK Negeri 2 Wonosari, Gunung Kidul. The result is that the developed jobsheet is feasible according to the expert and the user's point of view (students and teachers). Furthermore, this research is also relevant to the research of Noni Dwiki Putratantyo (2016) who has conducted research on the development of learning modules for projectbased workshop work techniques for industrial electronics engineering expertise program class $\mathrm{X}$ SMK. The result is that the developed module is feasible according to the expert and the user's point of view (students and teachers).

This research and relevant research both prove that the learning module of Workshop Work and Technical Drawing with the developed EPUB can improve student learning outcomes. The difference between this research and relevant research is in the type of research, the object of research and the subjects studied. But overall this research and relevant research both prove the success of the development of the Workshop Work learning module and Technical Drawing with thCONCLUSION

Based on the research findings of the development of the Workshop Work learning module and Technical Drawing using the EPUB that has been carried out, the following conclusions are obtained:

1. The development of learning modules according to the needs at SMKN 1 Sutera is carried out with the ADDIE development model, namely (analysis), (design), (development), (implementation), and (evaluation) has been successfully developed.

2. The learning module developed in the subject of Workshop Work and Technical Drawing for class $\mathrm{X}$ TAV students at SMKN 1 Sutera is valid and practical.

3. The EPUB-based Learning Module is used to determine the validity and practicality of the Workshop Work learning module and Technical Drawing for class X TAV students in SMK.

This research can provide input to the school, namely SMKN 1 Sutera, because the learning module "Workshop Work and Technical Drawing using the developed EPUB can improve learning outcomes in the subject of Workshop Work and Technical Drawing. The school can facilitate the implementation of learning by utilizing the Work Workshop and Technical Drawing learning module by facilitating students to access the module independently from home by providing subsidized quotas to each student, so that students can access the module easily and can take advantage of the module in the process learning ". Furthermore, the school can also save this developed learning module and use it in Workshop Work learning and Technical Drawing for future lessons.

\section{REFERENCES}

Ago, G., Suharno, Mintarti, S., \& Hariyadi, S. (2015). Effect Of Product Quality Perception , Trust , And Brand Image On Generic Drug Buying Decision And Consumer Satisfaction Of Hospital Patientsi In East Kalimantan. European Journal of Business and Management, 7(14), 50-69.

Asyhar, R. (2011). Kreatif mengembangkan media pembelajaran. Gaung Persada Press.

Audia, M. (2019). Pengembangan Media E-Book Dengan Bantuan Sigil Software Untuk Kelas Vii Mts AlHikmah Kedaton Bandar Lampung Pada Mata Pelajaran Fiqh.

Azwar, S. (2012). Realibilitas dan Validitas. Pustaka Pelajar.

Branch, R. M. (2009). Instructional Design: The ADDIE Approach.

Depdiknas. (2008). Pengembangan SMK Berstandar Nasional/Internasional. Departemen Pendidikan Nasional. Direktorat Pembinaan Sekolah Menengah 
Kejuruan.

Diana, W. (2020). Pengembangan Multimedia Interaktif Pada Mata Pelajaran Dasar Desain Grafis Kelas X di SMK Negeri 1 Painan. UNP.

Dwiki, N. (2016). Pengembangan Modul Pembelajaran Teknik Kerja Bengkel Berbasis Project Untuk Program Keahlian Teknik Elektronika Industry Kelas X SMK. Jurnal Vokasi, 5(2).

Hasbiyati, H., \& Khusnah, L. (2016). Pengembangan EBook Berekstensi Epub Pada Pembelajaran IPA SMP. Bioshell, 5(01), 298-305.

Majid, A. (2006). Perencanaan Pembelajaran. PT Remaja Rosdakarya.

Maran, Z. D. (2007). Peralatan Bengkel Otomotif. Andi.

Nasution. (2009). Modul Pembelajaran. Rineka Cipta.

Prasetyo, A. (2015). Pengembangan Job Sheet Teknik Kerja Bengkel Elektronika Sebagai Media Pembelajaran Praktik Siswa Kelas X di SMK Negeri 2 Wonosari. Jurnal Pendidikan, 2(1).

Pratama, S. O., \& Yuhendri, M. (2020). Pengembangan Modul Kerja Bengkel dan Gambar Teknik untuk Sekolah Menengah Kejuruan. Jurnal Pendidikan Teknik Elektro, 01(01), 62-66.

Riduwan. (2007). Pengantar Statistika untuk Penelitian. Alfabeta.

Rivai, A. (2011). Hakikat Pendidikan. Rineka Cipta.

Sudjana, N. (2005). Penilaian Hasil Proses Belajar Mengajar. Rineka Cipta.

Sugiyono. (2012). Metode Penelitian Kuantitatif,
Kualitatif dan $R \& D$. Rineka Cipta.

Susanto. (2011). EPUB. Alfabeta. 